CENDEKIA, Vol. 13. No. 1 April 2019

p-ISSN: 1978-2098; e-ISSN: 2407-8557

Https://soloclcs.org; Email: cendekiaoslo@gmail.com

Center of Language and Cultural Studies, Surakarta, Indonesia

Apandi, Yulianto \& Rosalia, Feni. 2019. Kinerja Pegawai Universitas Lampung

Ditinjau dari Gaya Kepemimpinan dan Motivasi Kerja.

Cendekia (2019), 13(1): 19-32. Https://doi.org/10.30957/cendekia.v13i1.54.

\title{
Kinerja Pegawai Universitas Lampung Ditinjau dari Gaya Kepemimpinan dan Motivasi Kerja
}

\author{
Apandi ${ }^{1}$, Yulianto \& Feni Rosalia
}

\author{
Program Studi Ilmu Administrasi, \\ Fakultas Ilmu Sosial dan Ilmu Politik, Universitas Lampung \\ 1Corresponding author: apandi.ad@gmail.com
}

\begin{abstract}
The purpose of this study was to determine the performance of Lampung University employees, through leadership style and work motivation. This study used a correlational quantitative approach. The population of this study was all employees of education staff at the General and Financial Devision at Lampung University of 110 people. Samples were taken purposively, as many as 53 employees. Data was collected using survey methods. The data were analyzed by simple and multiple linear regression with the help of SPSS 17.0 statistical software. Based on the results of testing the hypothesis of the influence of leadership style on employee performance, the results of t-count of 2.374 and t-table of 1.67655 were obtained. Furthermore, the motivation variables on employee performance, the results of $t$-count were 7.283 and t-table was 1.67655 . Simultaneous testing or jointly obtained results of F-count statistics of 40,288 and F-table 3.18. The results of the analysis can be concluded that employee performance at the General and Financial Bureau of Lampung University is influenced by motivation.
\end{abstract}

Keywords: performance, leadership, work motivation

Https://doi.org/10.30957/cendekia.v13i1.54.

\section{PENDAHULUAN}

Tenaga kependidikan adalah sumber daya manusia dalam hal ini PNS dituntut untuk memiliki kualitas dan profesionalisme, sehingga dapat melaksanakan tugas pokok dan fungsinya secara optimal, sebagaimana yang telah diatur dalam organisasi tata kerja. Sehingga diharapkan penyelenggaraan pemerintahan yang baik (good governance) dapat terlaksana seperti yang dicita-citakan bersama. Kenyataan terkait dengan kinerja tenaga kependidikan sendiri tidak terlepas sebagai Pegawai Negeri Sipil banyak disoroti dalam memberikan layanan.

Seperti yang diungkapkan Djimanto bahwa kinerja dan produktifitas birokrat Indonesia (Pegawai Negeri Sipil) sangat rendah jika dibandingkan dengan negara lain. Hal inilah yang membuat daya saing Indonesia, terutama dalam bidang ekonomi selalu tertinggal. Menurut Djimanto, ada beberapa hal mengapa kinerja dan poduktivitas 
CENDEKIA, Vol. 13. No. 1 April 2019

p-ISSN: 1978-2098; e-ISSN: 2407-8557

Https://soloclcs.org; Email: cendekiaoslo@gmail.com

Center of Language and Cultural Studies, Surakarta, Indonesia

Apandi, Yulianto \& Rosalia, Feni. 2019. Kinerja Pegawai Universitas Lampung

Ditinjau dari Gaya Kepemimpinan dan Motivasi Kerja.

Cendekia (2019), 13(1): 19-32. Https://doi.org/10.30957/cendekia.v13i1.54.

Pegawai Negeri Sipil (PNS) Indonesia rendah. Pertama, sistem rekrutmen PNS yang masih berkoluasi, korupsi dan nepotisme (KKN), bukan berdasarkan kompetensi. Kedua, kenaikan pangkat dan sistem penggajian PNS dilakukan secara berkala bukan berdasarkan prestasi kerja. Ketiga, sistem pengawasan internal PNS tidak berjalan.Karena ketiga hal di ataslah, kata Djimanto jangan heran kalau kinerja Pegawai Negeri Sipil (PNS) Indonesia rendah seperti malas-malasan, sering bolos, tidak produktif dan apalagi kalo liburan hari raya, PNS masuk kerja tidak tepat tanggal yang ditetapkan(Djimanto,2015).

Motivasi mempunyai peranan penting bagi pimpinan, sebab pimpinan dikatakan berhasil dalam menggerakkan bawahannya apabila dapat memberikan motivasi yang tepat. Peranan pimpinan sangat strategis dalam peningkatan motivasi kerja pegawainya agar mampu menyelesaikan tugas dengan tepat waktu, bergairah dalam bekerja dengan mendayagunakan sarana dan prasarana, menerapkan fungsi-fungsi manajemen, terutama fungsi motivasi dalam organisasi sehingga dapat menciptakan kondisi dan lingkungan yang nyaman dalam bekerja. Motivasi sebagai proses yang menjelaskan intensitas, arah, dan ketekunan seorang individu untuk mencapai tujuannya. Robbins (2009:222).

Selain faktor motivasi, kinerja pegawai juga dipengaruhi oleh gaya kepemimpinan yang diterapkan oleh pimpinan yang ada dalam suatu organisasi. Yusmalinda (2012:4). Setiap organisasi pemerintah maupun swasta, dalam mencapai tujuan yang telah ditetapkan harus melalui kegiatan-kegiatan yang digerakkan oleh orang atau sekelompok orang yang aktif berperan sebagai pelaku, tercapainya tujuan organisasi tidak dapat dilepaskan dari sumber daya yang dimiliki oleh organisasi yang digunakan atau dijalankan oleh pegawainya yang berperan aktif sebagaipelaku dalam upaya mencapai tujuan organisasi tersebut.

Gaya kepemimpinan berhubungan dengan ketenangan dalam melaksanakan tugas, peran kepemimpinan menjadi sangat penting untuk menentukan arah dan pencapaian tujuan organisasi. Seorang pemimpin akan memainkan peranan yang sangat dominan dalam kehidupan organisasinya, pemimpin dapat mempengaruhi semangat dan kegairahan dalam bekerja, kualitas kehidupan kerja dan tingkat prestasi suatu organisasi. Pimpinan harus mampu memberikan arah dan petunjuk kerja yang jelas kepada pegawai agar sesuai dengan tujuan organisasi. Pemimpin dituntut untuk mampu mengatur, mengarahkan, menggerakkan, memotivasi bawahannya serta mendelegasikan wewenang secara tepat, sehingga tujuan yang telah ditetapkan dapat dicapai secara optimal.

Menurut Thoha (1993:265) gaya kepemimpinan merupakan norma perilaku yang digunakan oleh seorang pada saat orang tersebut mencoba mempengaruhi perilaku orang lain seperti yang ia lihat. Dalam hal ini usaha menselaraskan persepsi diantara orang yang akan mempengaruhi perilaku dengan orang yang perilakunya akan dipengaruhi menjadi amat penting kedudukannya. Salah satu pendekatan yang dapat digunakan untuk mengetahui kesuksesan pemimpin ialah dengan mempelajari gayanya, karena gaya kepemimpinan banyak mempengaruhi keberhasilan seorang pemimpin 
CENDEKIA, Vol. 13. No. 1 April 2019

p-ISSN: 1978-2098; e-ISSN: 2407-8557

Https://soloclcs.org; Email: cendekiaoslo@gmail.com

Center of Language and Cultural Studies, Surakarta, Indonesia

Apandi, Yulianto \& Rosalia, Feni. 2019. Kinerja Pegawai Universitas Lampung

Ditinjau dari Gaya Kepemimpinan dan Motivasi Kerja.

Cendekia (2019), 13(1): 19-32. Https://doi.org/10.30957/cendekia.v13i1.54.

dalam mempengaruhi perilaku bawahannya. Gaya kepemimpinan yang dilakukan oleh atasan akan mempengaruhi kenyamanan pegawai dalam bekerja, dan mempengaruhi tinggi rendahnya kinerja pegawai.

Peran vital dan strategis kepala Biro Umum dan Keuangan Universitas Lampung selaku pimpinan organisasi dalam membangun semangat dan motivasi dilakukan dengan memadukan pendekatan persuasif dan profesionalisme. Konsep tersebut diawali dengan membuka komunikasi dengan seluruh pegawai dan mendengarkan berbagai saran dan keluhan yang disampaikan baik secara lisan maupun secara tertulis. Langkah ini dimaksudkan untuk dapat memetakan seluruh harapan dan keinginan dari para pegawai dalam melaksanakan tugasnya.

Keberadaan seorang pimpinan bukan sebagai penguasa yang dilayani, namun kehadirannya lebih sebagai pengarah dan penyusun strategi kerja yang profesional. Hal ini dapat dilakukan oleh seorang pimpinan manakala ia mengedepankan fungsi mata, hati, telinga, pikiran, dan perasaan secara objektif, namun tidak semua pimpinan mampu bersikap seperti apa yang tertuang dalam teori kepemimpinan. Hal ini dikarenakan setiap pimpinan adalah manusia biasa yang memiliki, sifat, karakter dan gaya tersendiri dalam memimpin.

Alasan peneliti tertarik dalam penelitian ini pertama ingin mengetahui bagaimana peran pimpinan sangat menentukan dalam memotivasi kinerja pegawai sehingga tujuan biro umum dan keuangan sebagai unsur pelaksanaan administrasi di Unila dalam menyelenggarakan pelayanan teknis dan adminsitratif akan dapat tercapai dengan baik..

Berdasarkan uraian di atas, dan latar belakang masalah maka perlu dilakukan penelitian untuk mengungkapkan pengaruh gaya kepemimpinan dan motivasi terhadap kinerja pegawai pada biro umum dan keuangan Universitas Lampung.

\section{LANDASAN TEORI}

Menurut Dubin dalam Wahjosumidjo (1994:21) "Leadership is the exercises of authority and the making of decisions" (Kepemimpinan adalah aktivitas para pemegang kekuasaan dan membuat keputusan). Dari pendapat Dubin dapat diartikan bahwa kepemimpinan itu adalah merupakan aktivitas yang dilakukan oleh para pemegang kekuasaan dalam membuat suatu keputusan.

Selanjutnya menurut Stogdill dalam Stonner (2003:161) "Kepemimpinan adalah suatu proses mengarahkan dan mempengaruhi aktivitas yang berkaitan dengan pekerjaan dan anggota kelompok". dari pendapat Stogdill dapat ditarik suatu pendapat bahwa kepemimpinan itu merupakan upaya dalam mempengaruhi dan mengarahkan suatu kelompok.

Kepemimpinan dalam organisasi diarahkan untuk mempengaruhi orang-orang yang dipimpinnya, agar mau berbuat seperti yang diharapkan ataupun diarahkan oleh orang lain yang memimpinnya (Sutikno, 2014:16).

Berdasarkan definisi kepemimpinan di atas dapat diartikan bahwa kepemimpinan adalah kemampuan seseorang dalam mempengaruhi, menggerakkan, mendorong, mengendalikan orang lain atau bawahannya untuk melakukan sesuatu pekerjaan atas 
CENDEKIA, Vol. 13. No. 1 April 2019

p-ISSN: 1978-2098; e-ISSN: 2407-8557

Https://soloclcs.org; Email: cendekiaoslo@gmail.com

Center of Language and Cultural Studies, Surakarta, Indonesia

Apandi, Yulianto \& Rosalia, Feni. 2019. Kinerja Pegawai Universitas Lampung

Ditinjau dari Gaya Kepemimpinan dan Motivasi Kerja.

Cendekia (2019), 13(1): 19-32. Https://doi.org/10.30957/cendekia.v13i1.54.

kesadarannya dan berkontribusi dalam mencapai suatu tujuan.

Teori kepemimpinan menurut Fiedler dalam Stonner (1996:173) bahwa mengukur gaya kepemimpinan pada skala yang menunjukkan tingkat seseorang menguraikan secara menguntungkan atau merugikan rekan sekerjanya yang paling tidak disukai (LPC, Least Preferred Co-worker).

Selanjutnya Fiedler dalam Wahjosumidjo (1994:97) mengindentifikasikan tiga macam situasi kepemimpinan atau variabel yang membantu menentukan gaya kepemimpinan yang efektif yaitu: a) Hubungan antara pemimpin dengan bawahan (leader-member relations). Maksudnya bagaimana tingkat kualitas hubungan yang terjadi antara atasan dengan bawahan. Sikap bawahan terhadap kepribadian, watak dan kecakapan atasan, b) Struktur tugas (task structure). Maksudnya di dalam situasi kerja apakah tugas- tugas telah disusun ke dalam suatu pola-pola yang jelas atau sebaliknya, c) Kewibawaan kedudukan pemimpin (leader's position power). Bagaimana kewibawaan formal pemimpin dilaksanakan terhadap bawahan.

Stoner (2003:134) menyatakan bahwa motivasi adalah karakteristik psikologi manusia yang memberi kontribusi pada tingkat komitmen seseorang. Ini termasuk faktor-faktor yang menyebabkan, menyalurkan dan mempertahankan tingkah laku manusia dalam arah tekad tertentu.

Dari berbagai definisi di atas dapat disimpulkan bahwa motivasi adalah sesuatu di dalam diri seseorang yang menyebabkan, menyalurkan dan mempertahankan tingkah lakunya untuk memenuhi kebutuhannya dalam mencapai kepuasan sesuai tujuannya.

Motivasi merupakan kekuatan pendorong yang akan mewujudkan suatu perilaku guna mencapai tujuan kepuasan dirinya. Motivasi terbentuk dari sikap seseorang pegawai dalam menghadapi situasi kerja. Motivasi merupakan kondisi yang menggerakkan diri pegawai yang terarah untuk mencapai tujuan organisasi, sikap mental merupakan kondisi mental yang mendorong diri pegawai untuk berusaha mencapai prestasi kerja secara maksimal.

Kinerja dalam sebuah organisasi merupakan salah satu unsur yang tidak dapat dipisahkan dalam suatu organisasi, baik itu organisasi publik maupun organisasi swasta. Kinerja organisasi akan sangat ditentukan oleh unsur pegawainya karena itu dalam mengukur kinerja suatu organisasi sebaiknya diukur dalam tampilan kerja dari pegawainya.

Istilah kinerja berasal dari kata Job Performance atau Actual Performance yang merupakan prestasi kerja atau prestasi sesungguhnya yang dicapai oleh seseorang. Mangkunegara (2011:67) mengatakan: Kinerja adalah hasil kerja secara kualitas dan kuantitas yang dicapai oleh seorang pegawai dalam melaksanakan tugasnya sesuai dengan tanggung jawab yang diberikan kepadanya.

Menurut Ruky (2001:14) menyatakan bahwa kinerja merupakan pengalih bahasaan dari bahasa Inggris performance yang diartikan oleh Bernardin dan Russel mendefinisikan kinerja sebagai pencatatan hasil-hasil yang diperoleh dari fungsi pekerjaan atau kegiatan tertentu selama kurun waktu tertentu.

Kinerja merupakan suatu gambaran mengenai tingkat pencapaian 
CENDEKIA, Vol. 13. No. 1 April 2019

p-ISSN: 1978-2098; e-ISSN: 2407-8557

Https://soloclcs.org; Email: cendekiaoslo@gmail.com

Center of Language and Cultural Studies, Surakarta, Indonesia

Apandi, Yulianto \& Rosalia, Feni. 2019. Kinerja Pegawai Universitas Lampung

Ditinjau dari Gaya Kepemimpinan dan Motivasi Kerja.

Cendekia (2019), 13(1): 19-32. Https://doi.org/10.30957/cendekia.v13i1.54.

pelaksanaan suatu kegiatan/program/kebijakan dalam mewujudkan sasaran, tujuan, misi, visi serta organisasi. Pada dasarnya pengertian kinerja berkaitan dengan tanggung jawab individu atau organisasi dalam menjalankan apa yang menjadi wewenang dan tanggung jawab yang diberikan kepadanya.

Dari berbagai definisi kinerja di atas, dapat disimpulkan bahwa Kinerja adalah suatu hasil kerja yang dapat dicapai seseorang atau sekelompok orang dalam suatu organisasi sesuai wewenang dan tanggung jawabnya untuk mencapai tujuan organisasi.

\section{METODE}

Jenis penelitian ini adalah penelitian kuantitatif korelational (Nazir, 1999). Penelitian dilakukan di Biro Umum dan Keuangan Universitas Lampung. Populasi penelitian ini yaitu sebanyak 110 orang, sedangkan sampel penelitian sebanyak 53 orang pegawai. Data dikumpulkan dengan menggunakan angket yang dikembangkan oleh peneliti berdasarkan teori yang ada. Sebelum uji hipotesis dilakukan uji validitas, reliabilitas, dan linieritas yang seluruhnya memenuhi syarat. Data dianalisis menggunakan uji regresi dengan satu prediktor (parsial), maupun regresi dua prediktor (simultan). Sebelum dilakukan uji hipotesis dilakukan uji asumsi klasik meliputi uji normalitas, linieritas, dan multikolinieritas, seluruhnya memenuhi syarat untuk dilanjutkan pada uji hipotesis.

\section{HASIL PENELITIAN}

\subsection{Karakteristik Responden}

Hasil penelitian yang dilakukan kepada responden menurut kelompok umur, maka dapat diketahui bahwa dari 53 orang sampel, terdapat 7 orang $(13,20 \%)$ responden berusia antara 20-29 tahun, sebanyak 19 orang $(35,85 \%)$ responden berusia antara 30-39 tahun, sebanyak 15 orang $(28,30 \%)$ responden berusia antara 40-49 tahun, dan sebanyak 12 orang $(22,64 \%)$ responden berusia 50 tahun ke atas. Dengan demikian maka sebagaian besar responden dalam penelitian ini berusia antara 30-39 tahun.

Hasil penelitian yang dilakukan kepada responden menurut jenis kelamin, maka dapat diketahui bahwa dari 53 orang sampel ada sebanyak 33 orang $(62,26 \%)$ responden berjenis kelamim laki-laki, dan 20 orang $(37,74 \%)$ responden berjenis kelamin perempuan. Dengan demikian maka sebagian besar responden penelitian ini berjenis kelamin laki-laki sebesar $62.26 \%$.

Hasil penelitian yang dilakukan kepada responden menurut pendidikan terakhir, maka dapat diketahui bahwa dari 53 orang sampel ada sebanyak 4 orang (7,57\%) responden berpendidikan Sekolah Menengah Pertama, sebanyak 16 orang $(30,18 \%)$ responden berpendidikan SMA, sebanyak 13 orang $(24,52 \%)$ responden berpendidikan Diploma, sebanyak 15 orang $(28,30 \%)$ responden berpendidikan Sarjana (S1), dan sebanyak 5 orang $(9,43 \%)$ responden berpendidikan Magister (S2). Dengan demikian maka sebagaian besar responden penelitian ini berpendidikan SMA sebesar $30,18 \%$. 
CENDEKIA, Vol. 13. No. 1 April 2019

p-ISSN: 1978-2098; e-ISSN: 2407-8557

Https://soloclcs.org; Email: cendekiaoslo@gmail.com

Center of Language and Cultural Studies, Surakarta, Indonesia

Apandi, Yulianto \& Rosalia, Feni. 2019. Kinerja Pegawai Universitas Lampung

Ditinjau dari Gaya Kepemimpinan dan Motivasi Kerja.

Cendekia (2019), 13(1): 19-32. Https://doi.org/10.30957/cendekia.v13i1.54.

Hasil penelitian yang dilakukan kepada responden menurut golongan pegawai negeri sipil, maka dapat diketahui bahwa dari 53 orang ada sebanyak 5 orang $(9,43 \%)$ responden golongan I, sebanyak 22 orang $(41,51 \%)$ responden golongan II, sebanyak 24 orang $(45,28 \%)$ responden golongan III, dan sebanyak 2 orang $(3,77 \%)$ responden golongan IV. Dengan demikian maka sebagaian besar responden dalam penelitian ini didominasi golongan III sebesar 45,28\%.

Berdasarkan hasil pengujian statistik deskriptif dapat dijelaskan bahwa nilai rata-rata keseluruhan variabel memiliki nilai yang berbeda, dari 3 variabel yang diteliti maka tingkat nilai terbesar ada pada nilai rata-rata Kinerja Karyawan yaitu sebesar 63,21 total keseluruhan. Nilai tersebut merupakan total jawaban instrumen yang diberikan oleh responden penelitian ini. Sebanyak 53 sampel penelitian, nilai minimum diberikan pada variabel Gaya Kepemimpinan yaitu sebanyak 28 total skor jawaban responden, nilai tersebut jauh diatas variabel Kinerja Pegawai yang memiliki nilai terendah atau minimum sebesar 54 total jawaban responden terkait Kinerja Pegawai dan sisanya sebesar 32 total skor diberikan pada Variabel Motivasi Kerja. Hal ini berarti bahwa Gaya Kepemimpinan pada objek penelitian tersebut memiliki antusiame yang rendah dibandingkan Motivasi Kerja serta Kinerja Karyawan pada Biro Umum dan Keuangan Universitas Lampung.

Untuk nilai maksimum atau nilai tertinggi skor jawaban responden, sebanyak 73 total skor jawaban responden berada pada variabel Kinerja Pegawai. Hal ini dapat dimaksudkan bahwa kinerja pegawai pada Biro Umum dan Keuangan Universitas Lampung dapat dikatakan cukup maksimal jika berkaca pada total skor jawaban responden tersebut. Akan tetapi, hal ini bukanlah hasil yang mutlak dan perlu dikaji secara statistik yaitu pada pengujian Regresi serta Uji Hipotesis. Nilai standar deviasi berdasarkan hasil pengujian statistik deksriptif pada tabel diatas menunjukkan bahwa nilai tertinggi standar deviasi berada pada variabel Motivasi $\left(\mathrm{X}_{2}\right)$ dengan nilai 7.57129.

Sedangkan nilai variance pada penelitian ini memiliki nilai tertinggi pada variabel Motivasi (X2) juga dengan nilai sebesar 57.324. Menurut Ghozali (2005) skewness dan kurtosis merupakan ukuran untuk melihat apakah data terdistribusi secara normal atau tidak. Skewness mengukur kemencangan dari data dan kurtosis mengukur puncak dari distribusi data. Data yang terdistribusi secara normal memiliki nilai skewness dan kurtosis mendekati nol. Hasil pengujian statistik deskriptif diatas menunjukkan bahwa nilai skewness dan kurtosis mendekati angka nol dan dapat dikatakan bahwa data tersebut terdistribusi secara normal.

Untuk mengetahui besarnya pengaruh variabel bebas faktor gaya kepemimpinan dan motivasi $\left(\mathrm{X}_{1}\right.$ atau $\left.\mathrm{X}_{2}\right)$ secara simultan terhadap variabel tidak bebas kinerja pegawai (Y) sekaligus untuk mengetahui koefisien regresi secara individu untuk mengetahui pengaruh dari variabel dependen terhadap variabel independen. 
CENDEKIA, Vol. 13. No. 1 April 2019

p-ISSN: 1978-2098; e-ISSN: 2407-8557

Https://soloclcs.org; Email: cendekiaoslo@gmail.com

Center of Language and Cultural Studies, Surakarta, Indonesia

Apandi, Yulianto \& Rosalia, Feni. 2019. Kinerja Pegawai Universitas Lampung

Ditinjau dari Gaya Kepemimpinan dan Motivasi Kerja.

Cendekia (2019), 13(1): 19-32. Https://doi.org/10.30957/cendekia.v13i1.54.

Tabel 1. Tabel Analisis Linear Berganda

\begin{tabular}{|l|l|r|r|}
\hline \multicolumn{2}{|c|}{ Model } & \multicolumn{2}{|c|}{ Unstandardized Coefficients } \\
\cline { 3 - 4 } \multicolumn{2}{|c|}{} & B & \multicolumn{2}{|c|}{ Std. Error } \\
\hline 1 & (Constant) & 26.461 & 4.334 \\
\cline { 2 - 4 } & Gaya Kepemimpinan & .229 & .084 \\
\cline { 2 - 4 } & Motivasi & .465 & .064 \\
\hline
\end{tabular}

Sumber: Data Penelitian, 2015

Berdasarkan data di atas secara simultan dapat dijelaskan bahwa analisis regresi berganda menghasilkan arah regresi $b_{1}$ sebesar 0.229 dan regresi $b_{2}$ sebesar 0,465 dengan nilai konstanta a sebesar 26.461. Dengan demikian pengaruh Gaya Kepemimpinan dan Motivasiterhadap Kinerja Pegawaidapat digambarkan melalui persamaan regresi:

$$
Y=26.461+0.229 X_{1}+0.465 X_{2}+e
$$

Hasil ini menunjukkan bahwa secara simultan apabila Gaya Kepemimpinan dan Motivasi ditingkatkan sebesar 1 satuan (\%), maka akan meningkatkan Kinerja Pegawai sebesar 0,229 dan 0,465 satuan (\%). Dari persamaam tersebut dapat dijelaskan dari hasil uji regresi linear berganda di atas sebagai berikut:

1. Jika kinerja pegawai dikatakan tetap dengan nilai sebesar 26.641 maka dapat diasumsikan ketika nilai Gaya kepemimpinan dinaikan sebesar satu satuan maka akan meningkatkan Kinerja Pegawai sebesar 0.229. Hal ini dapat dikatakan bahwa nilai dari kedua instrumen tersebut searah dan begitu pula sebaliknya jika nilai Gaya Kepemimpinan diturunkan sebesar satu satuan akan mengakibatkan penurunan Kinerja Pegawai pada Biro Umum dan Keuangan Universitas Lampung.

2. Jika kinerja pegawai dikatakan tetap dengan nilai sebesar 26.641 maka dapat diasumsikan ketika nilai Motivasi dinaikan sebesar satu satuan maka akan meningkatkan Kinerja Pegawai sebesar 0.465. Hal ini dapat dikatakan bahwa nilai dari kedua instrumen tersebut searah dan begitu pula sebaliknya jika nilai Motivasi diturunkan sebesar satu satuan akan mengakibatkan penurunan Kinerja Pegawai pada Biro Umum dan Keuangan Universitas Lampung.

\subsubsection{Uji $R^{2}$ (Koefisien Determinasi)}

Koefisien Determinasi $\mathrm{R}^{2}$ pada intinya mengukur seberapa jauh kemampuan model dalam menerangkan variasi variabel dependen. Nilai Koefisien Determinasi adalah antara 0 dan 1 . Nilai $\mathrm{R}^{2}$ yang kecil berarti kemampuan variabel-variabel independen dalam menjelaskan variasi variabel dependen amat terbatas. 
Tabel 2. Uji Koefisien Determinasi $\left(\mathbf{R}^{2}\right)$ Gaya Kepemimpinan dan Motivasi terhadap Kinerja Pegawai

\begin{tabular}{|r|r|r|r|}
\hline Model & R & R Square & \multicolumn{2}{|c|}{$\begin{array}{c}\text { Adjusted R } \\
\text { Square }\end{array}$} \\
\hline 1 & $.786^{\mathrm{a}}$ & .617 & .602 \\
\hline
\end{tabular}

Sumber: Data Penelitian, 2015

Berdasarkan hasil perhitungan di atas dapat diketahui nilai $\mathrm{R}$ adalah sebesar 0,786 sehingga secara simultan korelasi Gaya Kepemimpinan dan Motivasi terhadap Kinerja Pegawai termasuk kuat. Adapun nilai $\mathrm{R}^{2}$ (square) sebesar 0,617 artinya Gaya Kepemimpinan dan Motivasi dapat menjelaskan perubahan Kinerja Pegawai sebesar $61,7 \%$, sedangkan $38,3 \%$ dijelaskan oleh variabel lain.

\subsection{Pengaruh Gaya Kepemimpinan terhadap Kinerja Pegawai}

Pengujian hipotesis secara parsial pengaruh Gaya Kepemimpinan terhadap Kinerja Pegawaidigunakan rumus Uji t dengan hasil pada tabel 5.57. Hasil Uji thitung diperoleh nilai sebesar 2.734 sedangkan nilai $t_{\text {tabel }}$ untuk $n=53$ pada $\alpha=0,05$ adalah 1.67655. Hasil ini menunjukkan bahwa Gaya Kepemimpinan berpengaruh positif dan signifikan terhadap Kinerja Pegawai dengan hipotesis.

$\mathrm{Ha}_{1}$ : Terdapat pengaruh signifikan antara Gaya Kepemimpinan terhadap Kinerja Pegawai.

Ho1: Tidak terdapat pengaruh signifikan antara Gaya Kepemimpinan terhadap

Kinerja Pegawai.

Maka $\mathrm{Ha}_{1}$ diterima yaitu terdapat pengaruh yang signifikan antara Gaya Kepemimpinan terhadap Kinerja Pegawai Biro Umum dan Keuangan di Universitas Lampung.

\subsubsection{Pengaruh Motivasi terhadap Kinerja Pegawai}

Pengujian hipotesis secara parsial pengaruh Motivasi terhadap Kinerja Pegawai digunakan rumus Uji t dengan hasil sebagai berikut.

Tabel 3. Uji t

\begin{tabular}{|l|l|r|r|}
\hline \multicolumn{2}{|c|}{ Model } & t & Sig. \\
\hline 1 & (Constant) & 6.105 & .000 \\
\cline { 2 - 4 } & Gaya Kepemimpinan & 2.734 & .009 \\
\cline { 2 - 4 } & Motivasi & 7.283 & .000 \\
\hline
\end{tabular}

Sumber: Data Penelitian, 2015

Hasil Uji thitung diperoleh nilai sebesar 7.283 sedangkan nilai $t_{\text {tabel }}$ untuk $\mathrm{n}=53$ 
pada $\alpha=0,05$ adalah 1,6725 . Hasil ini menunjukkan bahwa Motivasi berpengaruh positif dan signifikan terhadap Kinerja Pegawai dengan hipotesis:

$\mathrm{Ha}_{2}$ : Terdapat pengaruh signifikan antara Motivasi terhadap Kinerja Pegawai.

$\mathrm{Ho}_{2}$ : Tidak terdapat pengaruh signifikan antara Motivasi terhadap Kinerja Pegawai.

Maka $\mathrm{Ha}_{1}$ diterima yaitu terdapat pengaruh yang signifikan antara Motivasi terhadap Kinerja Pegawai Tenaga Kependidikan Biro Umum dan Keuangan Universitas Lampung.

\subsubsection{Pengaruh Gaya Kepemimpinan dan Motivasi terhadap Kinerja Pegawai}

Hasil Uji F untuk menguji pengaruh simultan Gaya Kepemimpinan dan

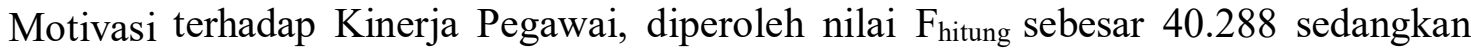
$\mathrm{F}_{\text {tabel }}$ dengan $\mathrm{n}=53$, diperoleh $\mathrm{F}_{\text {tabel }}=3.18$. Dengan hipotesis yang diajukan sebagai berikut.

Ha3: Terdapat pengaruh signifikan antara Gaya Kepemimpinan dan Motivasi terhadap Kinerja Pegawai.

Ho3: Tidak terdapat pengaruh signifikan antara Gaya Kepemimpinan dan Motivasi terhadap Kinerja Pegawai.

Kriteria pengujian sebagai berikut. Ho diterima bila $F_{\text {hitung }} \leq \mathrm{F}_{\text {tabel. }}$. Ho ditolak bila $F_{\text {hitung }} \geq F_{\text {tabel. }}$ Oleh karena $F_{\text {hitung }} \geq F_{\text {tabel }}$ maka dengan ini Ho ditolak yang berarti Gaya Kepemimpinan dan Motivasi terhadap Kinerja Pegawai memiliki pengaruh yang signifikan. Dengan demikian dari hasil tersebut membuktikan hipotesis yang diajukan yaitu "Terdapat pengaruh signifikan Gaya Kepemimpinan dan Motivasi terhadap Kinerja Pegawai Biro Umum dan Keuangan di Universitas Lampung" adalah benar terbukti.

\section{BAHASAN}

\subsection{Pengaruh Gaya Kepemimpinan terhadap Kinerja Pegawai}

Pada pengujian parsial atau uji $\mathrm{t}$ ditemukan hasil hubungan antara Gaya Kepemimpinan terhadap Kinerja Pegawai pada Biro Umum dan Keuangan Universitas Lampung sebesar 2.734 dan nilai $t_{\text {tabel }}$ sebesar 1.67655. dengan ini dapat dijelaskan bahwa nilai $t_{\text {hitung }}(2.734)>t_{\text {tabel }}(1.67655)$ dan pengaruh di antara keduanya dapat dikatakan signifikan. Hal ini tentunya dapat diperkuat berdasarkan hasil jawaban responden mengenai Gaya Kepemimpinan salah satunya adalah "Pimpinan memuji dan menghargai pegawai yang bekerja tepat waktu", hal ini mengindikasikan bahwa gaya pimpinan sangat disegani oleh pegawai dikarenakan mereka selalu mengapresiasi kinerja pegawai yang bekerja tepat pada waktunya.

Menurut Rivai (2014:42) menyatakan gaya kepemimpinan adalah sekumpulan ciri yang digunakan pimpinan untuk memengaruhi bawahan agar sasaran organisasi tercapai atau dapat pula dikatakan bahwa gaya kepemimpinan adalah pola perilaku dan strategi yang disukai dan sering diterapkan oleh seorang pemimpin. Gaya kepemimpinan yang menunjukkan, secara langsung maupun tidak langsung, tentang 
CENDEKIA, Vol. 13. No. 1 April 2019

p-ISSN: 1978-2098; e-ISSN: 2407-8557

Https://soloclcs.org; Email: cendekiaoslo@gmail.com

Center of Language and Cultural Studies, Surakarta, Indonesia

Apandi, Yulianto \& Rosalia, Feni. 2019. Kinerja Pegawai Universitas Lampung

Ditinjau dari Gaya Kepemimpinan dan Motivasi Kerja.

Cendekia (2019), 13(1): 19-32. Https://doi.org/10.30957/cendekia.v13i1.54.

keyakinan seorang pimpinan terhadap kemampuan bawahannya. Artinya gaya kepemimpinan adalah perilaku dan strategi, sebagai hasil kombinasi dari falsafah, keterampilan, sifat, sikap, yang sering diterapkan seorang pemimpin ketika ia mencoba memengaruhi kinerja bawahannya. Selanjutnya menurut Stonner (1996:165) menyatakan bahwa gaya kepemimpinan adalah berbagai pola tingkah laku yang disukai oleh pemimpin dalam proses mengarahkan dan mempengaruhi pekerja.

Gaya kepemimpinan menurut Hasibuan (2007) maka objek penelitian ini lebih

cocok digunakan Gaya Kepemimpinan Partisipatif yaitu apabila dalam kepemimpinannya dilakukan dengan cara persuasif, menciptakan kerja sama yang serasi, menumbuhkan loyalitas, dan partisipasi para bawahan. Pemimpin memotivasi bawahan agar merasa ikut memiliki organisai/instansi. Bawahan harus berpartisipasi memberikan saran, ide, dan pertimbangan dalam proses pengambilan keputusan. Pemimpin dengan gaya partisipatif akan mendorong kemampuan bawahan mengambil keputusan. Dengan demikian, pimpinan akan selalu membina bawahan untuk menerima tanggung jawab yang lebih besar.

Kinerja merupakan suatu kondisi yang harus diketahui dan dikonfirmasikan kepada pihak tertentu untuk mengetahui tingkat pencapaian hasil suatu instans i dihubungkan dengan visi yang diemban suatu organisasi atau perusahaan serta mengetahui dampak positif dan negatif dari suatu kebijakan operasional. Pengukuran kinerja merupakan suatu langkah yang harus dilakukan dalam upaya meningkatkan kinerja organisasi. Melalui pengukuran kinerja tingkat capaian

\subsection{Pengaruh Motivasi terhadap Kinerja Pegawai}

Pada pengujian parsial atau uji t ditemukan hasil hubungan antara Motivasi Kerja terhadap Kinerja Pegawai pada Biro Umum dan Keuangan Universitas Lampung sebesar 7.283 dan nilai tabel sebesar 1.67655. Dapat dijelaskan bahwa nilai thitung $(7.283)>t_{\text {tabel }}(1.67655)$ dan pengaruh diantara keduanya dapat dikatakan signifikan. Hal ini tentunya dapat diperkuat berdasarkan hasil jawaban responden mengenai Motivasi Kerja salah satunya adalah "Pimpinan saudara menghargai setiap hasil kerja yang saudara lakukan". Pimpinan tidak segan-segan menghargai setiap hasil kerja yang dilakukan pegawai, hal tersebutlah yang semakin memotivasi pegawai untuk meningkatkan kinerja mereka.

Motivasi merupakan kekuatan pendorong yang akan mewujudkan suatu perilaku guna mencapai tujuan kepuasan dirinya. Motivasi terbentuk dari sikap seseorang pegawai dalam menghadapi situasi kerja. Motivasi merupakan kondisi yang menggerakkan diri pegawai yang terarah untuk mencapai tujuan organisasi, sikap mental merupakan kondisi mental yang mendorong diri pegawai untuk berusaha mencapai prestasi kerja secara maksimal. Penelitian ini lebih cocok Jika dikaitkan dengan Teori kepuasan yang dikemukakan Hasibuan (2007) Teori ini mendasarkan pendekatan atas faktor-faktor kebutuhan dan kepuasan individu yang menyebabkannya bertindak dan berperilaku dengan cara tertentu.

Teori ini memusatkan perhatian pada faktor-faktor dalam diri seseorang 
CENDEKIA, Vol. 13. No. 1 April 2019

p-ISSN: 1978-2098; e-ISSN: 2407-8557

Https://soloclcs.org; Email: cendekiaoslo@gmail.com

Center of Language and Cultural Studies, Surakarta, Indonesia

Apandi, Yulianto \& Rosalia, Feni. 2019. Kinerja Pegawai Universitas Lampung

Ditinjau dari Gaya Kepemimpinan dan Motivasi Kerja.

Cendekia (2019), 13(1): 19-32. Https://doi.org/10.30957/cendekia.v13i1.54.

yang menguatkan, mengarahkan, mendukung dan menghentikan perilakunya. Teori ini mencoba menjawab pertanyaan kebutuhan apa yang memuaskan dan mendorong semangat bekerja seseorang. Hal yang memotivasi semangat bekerja seseorang adalah untuk memenuhi kebutuhan dan kepuasan materiil maupun nonmateriil yang diperolehnya dari hasil pekerjaannya.

Dari deskripsi fakta dilapangan dan dengan data-data di atas, menunjukan bahwa Kepala Biro Umum dan Keuangan Universitas Lampung memiliki gaya kepemimpinan situasional. Model kepemimpinan sangat baik untuk dilaksanakan pada Biro Umum dan Keuangan Universitas Lampung karena Karakteristik situasi atau keadaan sebagai faktor penentu utama yang membuat seseorang pemimpin berhasil melaksanakan tugas-tugas organisasi secara efektif dan efisien. Juga gaya ini membahas aspek kepemimpinan lebih mendasar watak kepribadian pemimpin. Gaya ini menyatakan bahwa faktor situasi lebih menentukan keberhasilan seorang pimpinan dibandingkan dengan watak pribadinya. Gaya kepemimpinan situasional berasumsi bahwa situasi yang berbeda membutuhkan tipe kepemimpinan yang berbeda pula.

Menurut Sutikno (2014) dalam mengembangkan gaya kepemimpinan situasional efektif dengan memadukan tingkat kematangan anak buah dengan pola perilaku yang dimiliki pimpinannya. Untuk kematangan para bawahannya agar bekerja sesuai yang dinginkan, maka peneliti merekomendasikan agar Kepala Biro Umum dan Keuangan Universitas Lampung harus menerapkan empat gaya yang efektif untuk diterapkan yaitu:

1. Pemimpin memberi instruksi dan mengawasi pelaksanaan tugas dan kinerja anak buahnya.

2. Pemimpin menjelaskan keputusannya dan membuka kesempatan untuk bertanya bila kurang jelas.

3. Pemimpin memberi kesempatan untuk menyampaikan ide-ide sebagai dasar pengambilan keputusan.

4. Pemimpin melimpahkan keputusan dan pelaksanaan tugas kepada bawahannya.

Dengan demikian dimensi gaya kepemimpinan yang digunakan dalam gaya ini adalah perilaku pimpinan yang berkaitan dengan tugas kepemimpinannya dan hubungan atasan-bawahan.

\section{SIMPULAN}

Berdasarkan hasil penelitian dapat disimpulkan:

1. Terdapat pengaruh yang signifikan antara Gaya Kepemimpinan $\left(X_{1}\right)$ terhadap Kinerja Pegawai (Y) pada Biro Umum dan Keuangandi Universitas Lampung dengan thitung diperoleh nilai sebesar 2.734 sedangkan nilai tabel untuk $n=53$ pada $\alpha=0,05$ adalah 1.67655. Hasil ini menunjukkan bahwa Gaya Kepemimpinan berpengaruh positif dan signifikan terhadap Kinerja Pegawai.

2. Terdapat pengaruh yang signifikan antara Motivasi $\left(\mathrm{X}_{2}\right)$ terhadap Kinerja Pegawai (Y) pada Biro Umum dan Keuangandi Universitas Lampung. Uji thitung diperoleh nilai sebesar 7.283 sedangkan nilai tabel untuk $\mathrm{n}=53$ pada $\alpha=0,05$ 
adalah 1,6725. Hasil ini menunjukkan bahwa Motivasi berpengaruh positif dan signifikan terhadap Kinerja Pegawai.

3. Terdapat pengaruh yang signifikan antara Gaya Kepemimpinan $\left(\mathrm{X}_{1}\right)$ dan Motivasi $\left(\mathrm{X}_{2}\right)$ terhadap Kinerja Pegawai $(\mathrm{Y})$ pada Tenaga Kependidikan di Biro Umum dan Keuangan Universitas Lampung. Diperoleh nilai $F_{\text {hitung }}$ sebesar 40.288 sedangkan $\mathrm{F}_{\text {tabel }}$ dengan $\mathrm{n}=53$, diperoleh $\mathrm{F}_{\text {tabel }}=3.18$.

\section{SARAN}

1. Diharapkan kedepannya untuk para pimpinan pada Biro Umum dan Keuangan Universitas Lampung mampu meningkatkan serta menyesuaikan Gaya Kepemimpinan yang disegani Karyawan demi meningkatkan baik dari segi Produktifitas maupun Kinerja Pegawai pada Biro Umum dan Keuangan Universitas Lampung.

2. Para pimpinan untuk memberikan pembagian tugas dan tanggung jawab kepada pegawai sesuai dengan kemampuan yang dimiliki serta sesuai dengan uraian tugas dan SOP yang berlaku.

3. Untuk penelitian selanjutnya, dapat mengembangkan ruang lingkup variabel lainnya terkait kinerja pegawai seperti pemberian reward, punishment, dan lingkungan kerja. Karena keterbatasan waktu peneliti belum mampu mengembangkan variabel tersebut.

\section{DAFTAR PUSTAKA}

Dwiyanto, 2001, Pengaruh Gaya Kepemimpinan, Iklim Organisasi dan Motivasi Kerja Terhadap Kinerja Pegawai Di Sekretariat Daerah Kabupaten Kendal, Tesis Magister Administrasi Publik Universitas Diponegoro, Semarang.

Handoko, T Hani, 2013, Manajemen Edisi Kedua, BPFE Gajah Mada, Yogyakarta.

Handoko, T Hani, 2012, Manajemen Personalia dan Sumberdaya Manusia Edisi Kedua, BPFE Gajah Mada, Yogyakarta.

Hasibuan, Malayu SP, 2007, Organisasi dan Motivasi, Bumi Akasara, Jakarta. Hasibuan. Malayu SP, 2007, Manajemen Sumber Daya Manusia, Bumi Aksara, Jakarta.

Historika, Novandri, 2012, Pengaruh Gaya Kepemimpinan dan Motivasi Kerja Terhadap Kinerja Pegawai pada Dinas Perhubungan Provinsi Kepulauan Riau. Tesis Magister Administrasi Publik Universitas Terbuka, Jakarta.

Irham. Fahmi, 2011, Manajemen Kinerja Teori dan Aplikasi, Alfabeta, Bandung.

Mangunegara, AA. Anwar Prabu, 2011, Manajemen Sumber Daya Manusia Perusahaan, Remaja Rosdakarya, Bandung.

Nawawi Uha. Ismail, 2013, Budaya Organisasi Kepemimpinan dan Kinerja, Kencana Prenadamedia Group, Jakarta.

Nazir, Mohammad, 1999, Metode Penelitian, Ghalia Indonesia, Jakarta.

Rencana Strategik Universitas Lampung Tahun 2011-2015, Bandar Lampung, 2012. 
Rivai, Zainal, Veithzal dkk, 2014, Kepemimpinan dan Perilaku Organisasi, Raja Grafindo Persada, Jakarta.

Robbins. Stephen P, 2002, Prinsip Prinsip Perilaku Organisasi Edisi ke Lima, Alih Bahasa Halida dan Dewi Sartika, Erlangga, Jakarta.

Ruki, Achmad S, 2001, Sistem Manajemen Kinerja, Gramedia Pustaka Utama, Jakarta.

Stoner, James AF, Freeman. R. Edward, Gilbert JR. Daniel R, 2003, Manajemen Jilid II, Alih Bahasa Alexander Sindoro, PT. Indeks Gramedia Grup, Jakarta.

Sugandha, Dann, 1986, Kepemimpinan Di Dalam Administrasi, Sinar Baru, Bandung.

Sutikno, Sobry, 2014, Pemimpin dan Kepemimpinan Tips Praktis untuk Menjadi Pemimpin yang Diidolakan, Holistica, Lombok.

Sutrisno, Edy. 2011, Budaya Organisasi, Kencana Prenada Media Group, Jakarta. Sutrisno, Edy. 2013, Manajemen Sumber Daya Manusia, Kencana Prenada Media Group, Jakarta.

Thoha, Miftah, 2013, Kepemimpinan dalam Manajemen, Raja Grafindo Persada, Jakarta.

Wahjosumidjo, 1985, Kepemimpinan dan Motivasi, Ghalia Indonesia, Jakarta.

Yukl, Gary, 2009, Kepemimpinan Dalam Organisasi Edisi ke Empat, Alih Bahasa Budi Supriyanto, Indeks, Jakarta.

Yusmalinda, 2012, Pengaruh Motivasi dan Gaya Kepemimpinan terhadap Kinerja Pegawai pada Dinas Pendidikan Kabupaten Bungo, Tesis Magister Manajemen Universitas Terbuka, Jakarta. 
CENDEKIA, Vol. 13. No. 1 April 2019

p-ISSN: 1978-2098; e-ISSN: 2407-8557

Https://soloclcs.org; Email: cendekiaoslo@gmail.com

Center of Language and Cultural Studies, Surakarta, Indonesia

Apandi, Yulianto \& Rosalia, Feni. 2019. Kinerja Pegawai Universitas Lampung

Ditinjau dari Gaya Kepemimpinan dan Motivasi Kerja.

Cendekia (2019), 13(1): 19-32. Https://doi.org/10.30957/cendekia.v13i1.54. 